\title{
Morphological diversity, total phenolic and flavonoid content of Echinacea purpurea cultivated in Karangpandan, Central Java, Indonesia
}

\author{
DWI FAJAR SIDHIQ ${ }^{1, \vartheta}$, YULI WIDIYASTUTI ${ }^{2}$, DYAH SUBOSITI ${ }^{2}$, BAMBANG PUJIASMANTO ${ }^{3}$, \\ AHMAD YUNUS ${ }^{3,4 \vee \varphi}$ \\ ${ }^{1}$ Graduate School, Department of Agronomy, Universitas Sebelas Maret. J1. Ir. Sutami 36A, Surakarta 57 126, Central Java, Indonesia. \\ Tel./fax.+62-271-637457, `email: dwifajars1402@gmail.com. \\ ${ }^{2}$ Researcher of Research and Development Center for Medicinal Plant and Traditional Medicines. Jl. Lawu, Kalisoro, Tawangmangu, Karanganyar \\ 57792, Central Java, Indonesia \\ ${ }^{3}$ Department of Agrotechnology, Faculty of Agriculture, Universitas Sebelas Maret. Jl. Ir. Sutami 36 A, Surakarta 57126, Central Java, Indonesia. \\ Tel./fax. +62-271-637457, ^vemail: yunusuns17@gmail.com \\ ${ }^{4}$ Center of Biotechnology and Biodiversity, Research and Development, Universitas Sebelas Maret. Jl. Ir. Sutami 36 A, Surakarta 57126, Central Java, \\ Indonesia
}

Manuscript received: 19 December 2019. Revision accepted: 29 February 2020.

\begin{abstract}
Sidhiq DF, Subositi D, Widiyastuti Y, Pujiasmanto B, Yunus A. 2020. Morphological diversity, total phenolic and flavonoid content of Echinacea purpurea cultivated in Karangpandan, Central Java, Indonesia. Biodiversitas 21: 1265-1271. Purple coneflower (Echinacea purpurea (L.) Moench) is a medicinal plant introduced from North America. While it has been introduced to Indonesia long several decades ago. E. purpurea has not been developed as a raw material for herbal medicines in Indonesia as it faces constraints, namely non-uniform production and lack of information on the total phenolic and flavonoid content if cultivated in the country. This study aims to determine the morphological diversity, total phenolic and flavonoid content of three accession E. purpurea cultivated on lowland area (i.e. $493 \mathrm{~m}$ asl) in Tegalgede, Karangpandan, Central Java, Indonesia. This study used a Randomized Complete Group Design (RCBD) method with 1 factor, namely 3 accessions of E. Purpurea: A1, A2, A3 each with four replications. Morphological observations, as well as laboratory analysis, were done in this research to collect quantitative and qualitative data. The quantitative data were analyzed using SPSS to test the difference. We found there is significantly different results E. Purpurea accession in term of plant height, wet stover weight, number of leaves, root weight, root length, number of branches. Quantitative observation in the form of extract yield, total phenol content and total flavonoid highest content of extract residue produced by Accession 3 with 7,655\%, while the highest phenolic was produced by Accession 1 with 507,619 mg GAE.g -1 extract, and the highest flavonoid was produced by Accession 2 with 313,869 mg QE.g-1 extract. This study concludes that there is morphological diversity of E. purpurea cultivated in Karangpandan with a significant correlation of accession to residue extract, phenolic, and flavonoid content.
\end{abstract}

Keyword: Echinacea purpurea, flavonoid, phenol

\section{INTRODUCTION}

Purple Coneflower (Echinacea purpurea (L.) Moench) is one of the introduced medicinal plants originating from North America, and is known as an important medicinal plant. E. purpurea has benefits for humans as immunoregulation, anti-inflammatory, and antioxidant and has no side effects or hypersensitivity in clinical trials. These species contain secondary metabolites including phenols, caffeic acid derivatives, alkamides, flavonoids, and polysaccharides and glycoproteins (Bruni R et al. 2018). Alkamides and caffeine acid derivatives are active compounds that show immunoregulatory effects (Lee et al. 2010). E. purpurea also has an antiviral, antibacterial and antifungal function (Acikgoz et al. 2018). Parts that can be used as raw materials for immune system enhancing drugs are extracts from all parts of E. purpurea, such as leaves, stems, roots, and flowers (Megha Gupta et al. 2012).

Since E. Purpurea is an introduced species, a good adaptation of $E$. purpurea can create a quite promising opportunity for the development of this species for medicinal uses and products in Indonesia. Nonetheless, not much research and development efforts have been conducted. E. purpurea as a raw material for herbal medicines in Indonesia experienced constraints, namely non-uniform and non-optimal production.

Echinacea purpurea has a native growing habitat in the four-season country, where the conditions for optimal growth are low temperatures and full sun exposure. Climate differences between subtropical and tropical countries will certainly affect plant morphology and genetics. Indonesia has tropical climate which is characterized by frequent high temperatures and small annual variations, and rain can almost occur at any time of the year (Center for Research and Development, 2010). The results of previous studies by Rahardjo (2005) showed that $E$. purpurea is well adapted in the tropical areas within altitudinal ranges of 400-1200 meters above sea level (m asl). The best growth of E. purpurea occurs at an altitude of 800 meters above sea level with rainfall of 2,000-3,000 
$\mathrm{mm} /$ year and types of andosol and latosol soil in West Java (Cianjur, Cibadak, Pacet) and Central Java (Klepu, Ungaran, Kaligentong, Ngagrong) that have good physical properties with high organic matter content (Rahardjo, 2000). However, the diversity of E. purpurea themselves has not been given much attention to maximize production.

Echinacea purpurea cultivated in Indonesia has undergone many morphological changes. Morphological changes are influenced by many factors altitude, temperature, humidity, intensity of sunlight, seasons, etc. Up to these days, morphological characters are still used as a basis for plant classification. Classifications based on morphological characteristics can be used as an appropriate general reference and considered as a fast method for the compilation of plant diversity maps, especially Angiosperms. Morphological properties can be observed more easily and practically compared with other properties (Jones and Luchsinger, 1986).

Nowadays, morphological markers are still used in some plants to cluster certain groups for a particular aim. For example, Susila et al. 2019 irradiated chrysanthemums with different doses of gamma rays which produced chrysanthemum flowers that have different morphology, thus morphological marking is carried out to classify some chrysanthemum flowers, accordingly, with the best results were obtained through the gamma-ray irradiation. Another study that still used morphological markers to classify plant diversity was conducted by Tantasawat et al. (2010) on string beans.

The morphological diversity of E. purpurea cultivated in Indonesia is presumably to be high since the original habitat of this species, which is North America, has different climatic condition to Indonesia. This study aims to determine the morphological diversity, total phenolic content and flavonoid content of three accessions of $E$. purpurea cultivated in lowland area (i.e. $493 \mathrm{~m}$ asl) in Tegalgede, Karangpandan, Central Java, Indonesia.

\section{MATERIALS AND METHODS}

\section{Study period and area}

This research was conducted from July to November 2019 in the experimental garden of the Center for Research and Development of Medicinal Plants and Traditional Medicine (B2P2TOOT), Karangpandan, Karanganyar Central Java, Indonesia (493 $\mathrm{m}$ asl).

\section{Field experimental procedure}

\section{Collection and identification of accession}

The E. purpurea accession was firstly obtained by PT Deltomed Laboratories which directly imported this species from Germany. The accession selection was based on a mass selection conducted in 2011 by previous B2P2TOOT garden researchers. Identification of accessions was chosen based on the differences in morphology of flower shape, flower color, stem color and leaf shape (Figure 1). The results of the selection conducted by Subositi and Fauzi (2012) showed that eight variants have resulted from two accessions of $\mathrm{BH} 2$ and BHU3. The accession has different morphological variations from its parents, especially in the flower morphology. Parental accessions of 1,2 and 3 flower shapes tend to curve downward, but there are differences in flower color, stem color, leaf shape, edge, and leaf tip. These three accessions came from same field experiments in Tawangmangu, Karanganyar Central Java (highland). Genetic construction of this accession was investigated using the ISSR method and there is polymorphism between accession 1 and others (unpublished data).

\section{Preparation of seeds and seedlings}

Echinacea purpurea seeds were collected based on the morphological similarities in flowers, leaves, stem colors, etc. The selected accession is the one chosen from the mass selection of the B2P2TOOT garden collection in 2011. The selected accessions were then harvested at the age of 4 months old, which then harvested, cleaned and fully dried. The dried seeds were then soaked in water for one night. Subsequently, they were planted to grow as seedlings until the age of 1.5 months.

\section{Planting and maintenance}

The 1.5-month-old E. purpurea seedling was transplanted to the experimental field. There are 3 blocks on the same location, each block has four beds as replication. Block one for Accession 1, block two for Accession 2, and block three for Accession 3. Afterward, it was planted on beds with an area of $2 \times 2 \mathrm{~m}$ with a height of $30 \mathrm{~cm}$ and a spacing of $45 \mathrm{~cm}$ between plants. Beds are made with a mixture of soil and organic fertilizer as much as $5 \mathrm{~kg} / \mathrm{m}^{2}$.

Watering was done daily every morning or afternoon. Weed cleaning was done once every two weeks and fertilizing was done one month after planting using organic fertilizer as much as $5 \mathrm{~kg} / \mathrm{m}$. Weed cleaning and pest control were done manually by hand.

\section{Observation}

Observations were conducted once a week, which included plant height measurement and leaves counting. Morphological observations were made when the $E$. purpurea entered its generative phase.

\section{Harvesting}

Harvesting was done at the age of 4 months after planting ( $80 \%$ flowering). Qualitative observations were conducted on the shape of the flower, the color of the flower, the shape of the crown of the flower, the color of the leaf, the shape of the leaf tip, the shape of the leaf's edge, the top and bottom surface of the leaf. While quantitative observation is done by measuring the plant height, wet stover weight, number of leaves, number of branches, number of flowers, root weight, and root length. Analysis of extract yield, total phenolic, and flavonoid content were parts of quantitative measurement. 


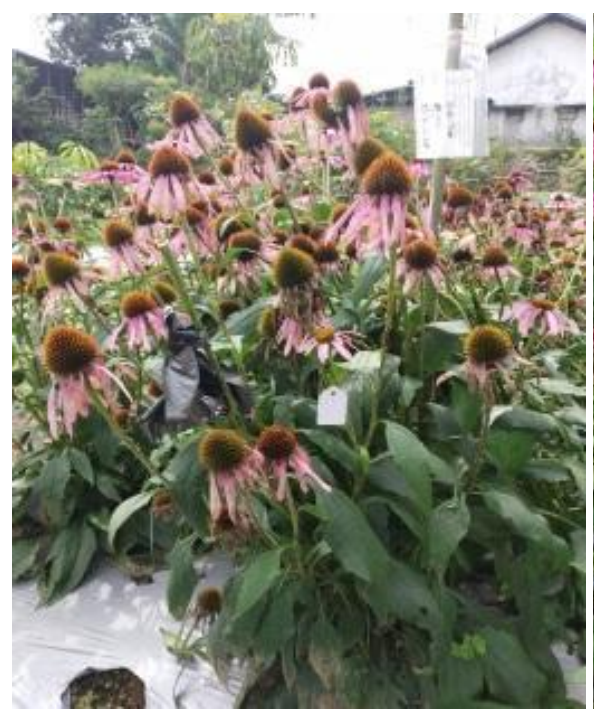

A

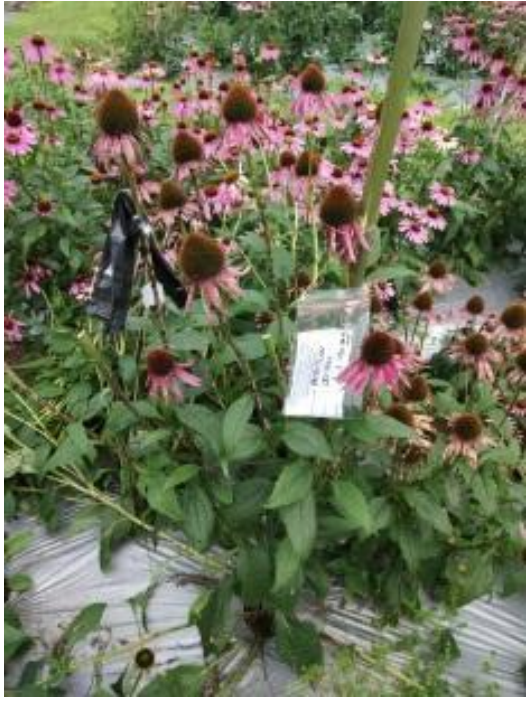

B

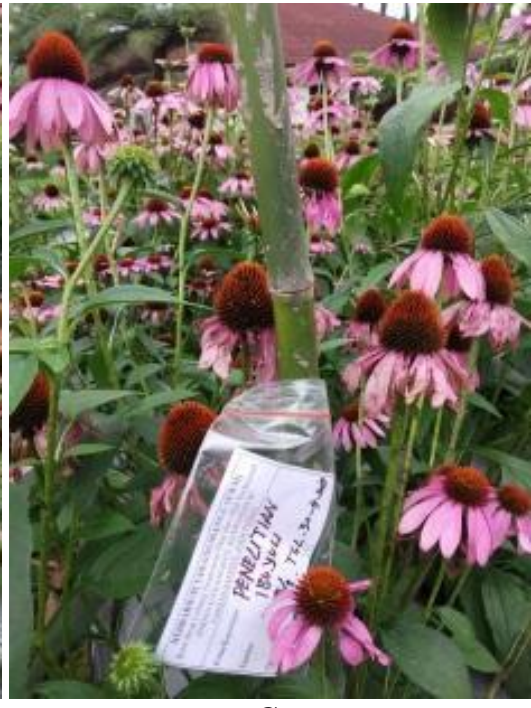

C

Figure 1. Selection of accessions as seeds: A. Accession 1, B. Accession 2, C. Accession 3

\section{Extraction}

After harvesting was completed, then the stover was dried using an oven with a temperature of $50^{\circ} \mathrm{C}$. The part of the plant taken was the upper parts of the plant or its herbs (stems, leaves, and flowers), which was dried for about 14 days. The dried stover was thoroughly ground until smooth, weighed as much as 5 grams for extract residue, and $100 \mathrm{mg}$ for analysis of phenolic and flavonoid. Samples that had been weighed were soaked with $50 \mathrm{~mL}$ absolute ethanol for extract residue and, $10 \mathrm{~mL}$ were used for each of phenols and flavonoids analysis. Samples for extract residue were macerated 3 x 24 hours, then filtrated and placed in a cup that was weighed beforehand and dried using an oven. The dried extract was weighed and calculated by subtracting the initial weight of the cup with the final weight of the cup.

\section{Determination of total phenolic}

Phenolic was analyzed using the Folin-Ciocalteau (FC) method with slight modification according to the Center for Research and Development of Medicinal Plants and Traditional Medicine (B2P2TOOT). This method was based on the reaction of the phenolic group with FolinCiocalteu reagent, i.e. the sample that is reacted will change color to a complex blue (Alfian and Susanti 2012).

\section{Preparation of gallic acid stock solution}

Gallic acid stock solution of 1000 ppm was prepared by dissolving $1 \mathrm{~g}$ of gallic acid with $1000 \mathrm{~mL}$ distilled water in $1000 \mathrm{~mL}$ volumetric flask. The solution is homogenized by shaking, then it was poured into $1 \mathrm{~L}$ Duran bottle and covered with aluminum foil.

\section{Preparation of $1 \mathrm{M} \mathrm{Na}_{2} \mathrm{CO}_{3}$ solution}

As much as $10,599 \mathrm{~g}$ of $\mathrm{Na}_{2} \mathrm{CO}_{3}$ was inserted in a 100 $\mathrm{mL}$ volumetric flask. Aquabidest was added up to the volume of $100 \mathrm{~mL}$.

\section{Determination of maximum wavelength}

The determination of wavelength was done by diluting the gallic acid stock solution to $60 \mathrm{ppm}$. Then, $300 \mu \mathrm{L}$ of $60 \mathrm{ppm}$ gallic acid solution was pipetted into the test tube and $400 \mu \mathrm{L}$ of Folin-Ciocalteau reagent was added and incubated for 8 minutes. As much as $2400 \mu \mathrm{L}$ of $\mathrm{Na}_{2} \mathrm{CO}_{3}$ was then added to the solution and incubation was done for 30 minutes. The solution was inserted into a cuvette and read at the wavelength of $500 \mathrm{~nm}-800 \mathrm{~nm}$ using UV-vis Spectrophotometer 1900 (Shimadzu brand). The maximum wavelength obtained was $757 \mathrm{~nm}$.

\section{Determination of the operating time}

Two test tubes were prepared as measurement blanks and gallic acid samples. The blank contained $400 \mu \mathrm{L}$ FolinCiocalteau, $2400 \mu \mathrm{L} \mathrm{Na} \mathrm{CO}_{3}$ and $300 \mu \mathrm{L}$ Aquabidest. As for the sample, it contained $400 \mu \mathrm{L}$ Folin-Ciocalteau 400 $\mu \mathrm{L}, 2400 \mu \mathrm{L} \mathrm{Na} \mathrm{CO}_{3}$, and $300 \mu \mathrm{L} 60$ ppm gallic acid. Solutions were incubated for 30 minutes, then inserted into a cuvette and read at $757 \mathrm{~nm}$ for 1 hour, starting from 0 minutes to 60 minutes with a period of 5 minutes. The most stable and maximum operating time was at 30 minutes.

\section{Making a standard curve}

Several concentrations of $30 ; 40 ; 50 ; 60 ; 70$ ppm were made from the $1000 \mathrm{ppm}$ gallic acid stock solution. As much as $300 \mu \mathrm{L}$ of each concentration was transferred into a test tube, $400 \mu \mathrm{L}$ Folin-Ciocalteau and $2400 \mu \mathrm{L} \mathrm{Na}_{2} \mathrm{CO}_{3}$ were added, then incubation for 30 minutes was done (sample). Whereas as the measurement blank, a solution containing $400 \mu \mathrm{L}$ Folin-Ciocalteau, $2400 \mu \mathrm{L} \mathrm{Na}_{2} \mathrm{CO}_{3}$ and $300 \mu \mathrm{L}$ Aquabidest were used. Each concentration was read at a wavelength of $757 \mathrm{~nm}$. The results were then calculated by the equation of $\mathrm{y}=\mathrm{bx}-\mathrm{a}$, and $\mathrm{R} 2$ obtained is 0.9661 . 


\section{Sample preparation}

Samples from extraction (100 mg dry sample in $10 \mathrm{~mL}$ absolute ethanol) were sonicated at $40 \mathrm{~Hz}$ for 15 minutes. After that, they were settled for 10 minutes, $300 \mu \mathrm{L}$ of sonication samples are taken and $400 \mathrm{~mL}$ of FolinCiocalteau was added. Incubated for 3 minutes, then 2400 $\mu \mathrm{L} \mathrm{Na} \mathrm{CO}_{3}$ was added and incubated for 30 minutes. The sample was pipetted into the cuvette and read at a wavelength of $757 \mathrm{~nm}$ to calculate the absorbance.

\section{Determination of total phenolic content}

Phenolic content in dried samples of E. purpurea herbs was obtained by calculating the absorbance values using the standard gallic acid curve with the curve equation of $y$ $=0.014 \mathrm{x}-0.188$. The measurement results for phenol levels were expressed as milligrams of gallic acid equivalent per gram of extract weight (mg GAE g-1).

\section{Determination of total flavonoid}

Analysis of total flavonoid levels was done using the Aluminum chloride colorimetric method from Chang et al. (2002) with a slight modification. The standard curve of identifiers used quercetin in methanol. Quercetin is one of the biologically strong flavonoid class active substances. The absorbance of the sample solution and the standard curve was measured by UV-Vis Spectrophotometer with a wavelength of $415 \mathrm{~nm}$. The flavonoids content in dried samples of herbaceous E. purpurea was obtained by calculating the absorbance value on the standard quercetin curve with the curve equation of $y=0.0383 x+0.0911$. The results of measurements of flavonoid content are expressed as milligrams of quercetin equivalent per gram of dry weight (mg GAE g-1).

\section{Data analysis}

Qualitative data were described descriptively and quantitative data were analyzed using SPSS 21.0 to produce the coefficient of regression.

\section{RESULTS AND DISCUSSION}

Of 192 E. purpurea plants, a total of 157 plants (or more than 80\%) did flowering and 96 E. purpurea of them were used as samples. E. purpurea that did not produce flowers has a dwarf-like appearance in comparison to samples that able to adapt well in the studied area which has lowland. Some E. purpurea did not flower due to stress during planting as the experiment was conducted during the dry season and the plant experienced stress. Drought causes photosynthetic rates to decrease significantly at all stages of growth (Akram et al, 2013). This causes the plant to become stunted, which causes the value of dry weight and plant productivity to decrease.

\section{Morphological characters Leaf}

The three accessions of E. purpurea cultivated in the studied areas have several differences that can be directly noticed. Accession 1 has the shape of an elongated ovate leaf and a tapered tip, the edge of a large, pointed jagged leaf, a deep green color. The upper surface of the leaf is rough and the bottom surface is rough-haired. This accession is very different from the parental morphology which might be due to the cross-pollination that occurred in the experimental garden. E. purpurea is a plant that has self-incompatibility (Subositi and Widyastuti 2013) so that there is a high diversity of leaf morphology compared to its previous parents. Accessions 2 and 3 have the same leaf color which is dark green, the shape of the leaves of the two accessions has jagged curved leaf edges and pointed edges. The lower surface of Accessions 2 and 3 is coarse hair, but the upper surface of the Accession 2 is smooth in contrast to Accession 3 with rough upper leaf texture (Figure 2).

\section{Flower}

The flower of $E$. purpurea is the most obvious morphological parameter that can be directly noticed. $E$. purpurea belongs to family of Asteraceae, similar family with Chrysanthemum which has a similar flower morphology and arrangement as E. purpurea which consists of tubular flowers, sepals, petals, and stems (Purnobasuki et al. 2014). The form of E. purpurea flower that is cultivated in the lowland has experienced many changes correlated to its parental. Almost all the accessions chosen have a form of a curved downward flower. However, after conducting research on the lowland, the shape of the flower of each accession underwent a different change. Accessions 1 and 3 have flowers that tend to be flat, while Accession 2 has flowers that tend to curve downward (Figure 3). The changes that occurred on the flower form is due to cross-breeding between one accession to another, which is in line with the study of Kang et al. (2015) that states the Hibiscus rosa-sinensis plant is crossed with an intraspecific hybridization that produces flowers with different colors, shapes, and sizes. The flower buds of Accession 1 have a light green color, while Accession 2 and Accession 3 have pink green (Figure 4). Research conducted in Germany also proves that there is a diversity of $E$. purpurea morphology, namely 7 accessions (Banga et al. 2010) and 9 E. purpurea genotypes (Varban et al. 2010). Accession 1 has deep pink flowers, Accession 2 has a pale pink color, but Accession 3 has a dark purple color (Figure 3). E. purpurea petals have different ends, Accession 1 has a notched 1 or " $\mathrm{V}$ " shaped tip, whereas the Accession 2 and Accession 3 have a groove or "W" shape.

The stems of $E$. purpurea also have morphological variations that can be seen easily from the color of the stems (Figure 5). Accession 1 has a light green stem with dark green spots, Accession 2 has a green stem with purple spots, while Accession 3 has a dark green color with light green spots. Color changes can be caused due to lack of sunlight, lack of nutrition, or can also be caused by a lack of water (Pratiwi et al. 2019). Plant morphology, including changing plant stems can be influenced by metabolic processes in plants and external factors such as temperature, humidity, stress, etc. Each plant has a different tolerance level for environmental changes that occur (Allen et al. 2010). The different stem morphology 


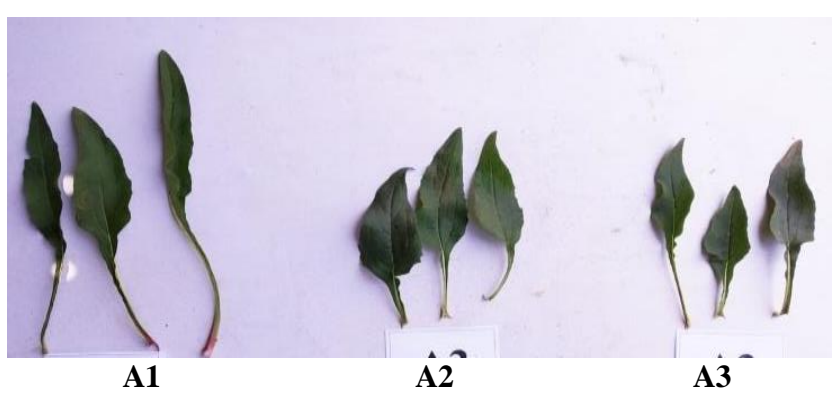

Figure 2. Leaf morphology of E. purpurea used in this study: A1. Accession 1, A2. Accession 2, A3. Accession 3

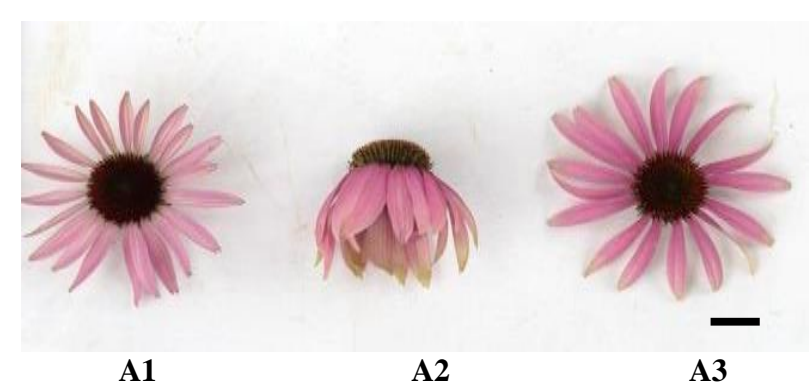

Figure 3. Flower morphology of E. purpurea used in this study: A1. Accession 1, A2. Accession 2, A3. Accession 3. Bar $=2 \mathrm{~cm}$

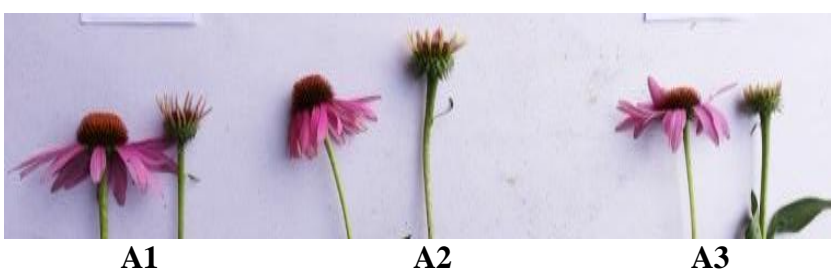

Figure 4. Flower and buds morphology of E. purpurea used in this study: A1. Accession 1, A2. Accession 2, A3. Accession 3

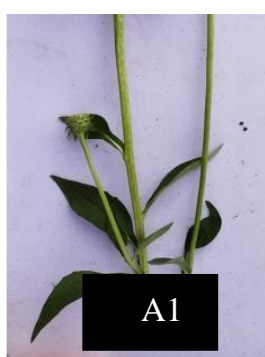

A1

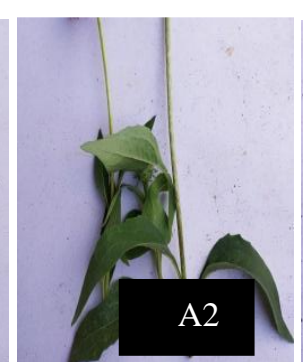

A2

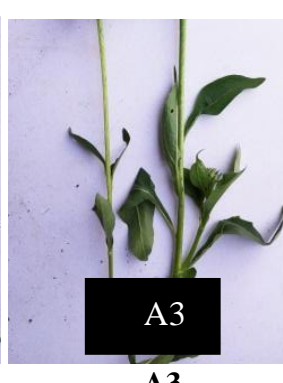

A3
Figure 5. Stem morphology of E. purpurea used in this study: A1. Accession 1, A2. Accession 2, A3. Accession 3 of E. purpurea in this study is likely caused by their tolerance to change in different environmental conditions.

\section{Stem}

\section{Extract residue}

Extract residue is obtained from the extraction process, which is the withdrawal of soluble chemical contents so that it is separated from insoluble materials with solvents such as water. Soft simplicia such as rhizomes and leaves are easily absorbed by solvents, therefore the extraction process does not need to be in the form of powder. In contrast in this extraction, E. purpurea needs to be powdered because the sample is in the form of stems, leaves and flowers mixture which has a quite hard texture. Hard simplicia such as seeds, stems, and bark must be ground until smooth (Ditjen POM, 2000). There are several methods of extraction, namely percolation, soxhlation, maceration infusion, digestion, etc. E. purpurea extraction is used to determine the yield of this extract using the maceration method. The result of extraction processes is presented in Table 1. The table shows that the highest extract yield was produced by Accession 3 with a value of $7.655 \%$, which is significantly different in comparison with Accessions 1 and 2.

\section{Total phenolic content}

Phenolic compounds are secondary metabolites of plants that have biological activities and consist of 8000 kinds of compounds. This phenolic compound can function as anti-Alzheimer's, anti-analgesic, and also antiallergic as stated by Shahidi and Yeo (2018). Our study shows that the total phenolic produced from 3 accessions of E. purpurea has significantly different results. The highest phenol yield was obtained from Accession 1 with 507,619 mg GAE.g-1 Extract, followed by accession 2 and 3 with a total content of 441,309 mg GAE.g-1 Extract and 397,917 mg GAE.g-1 Extract respectively.

\section{Total flavonoid content}

Flavonoids are a group of secondary metabolites that are synthesized from pyruvic acid through amino acid metabolism. The naming of flavonoids comes from Latin which refers to the color yellow, and most of the flavonoids are colored yellow. Flavonoids are groups of organic pigments that do not contain nitrogen molecules. The combination of pigments formed the color of leaves, flowers, stems, and fruit in plants. The pigment is also beneficial for humans and one of its benefits is as an antioxidant (Heldt and Piechulla 2011). For humans, flavones in small doses work as stimulants in the heart and capillaries, as well as diuretics and antioxidants in fats (Nijveld et al, 2001). Based on this study, the total flavonoid content produced was significantly different. Accession 2 produced the highest total flavonoid with a value of 313,869 mg QE.g-1, followed by Accession 1 with 298,214 mg QE.g-1, and accession 3 with the content of 290,952 mg QE.g-1. 
Table 1. Total phenolic and flavonoid content in herbs ethanolic extract

\begin{tabular}{lccc}
\hline Accession & $\begin{array}{c}\text { Rendement extract } \\
(\%)\end{array}$ & $\begin{array}{c}\text { Total phenolic content } \\
(\text { mg GAE.g-1 Extract) }\end{array}$ & $\begin{array}{c}\text { Total flavonoid content } \\
(\mathbf{m g} \text { QE.g-1 Extract) }\end{array}$ \\
\hline 1 & $6,943^{\mathrm{a}}$ & $\mathbf{5 0 7 , 6 1 9}^{\mathrm{c}}$ & $298,214^{\mathrm{a}}$ \\
2 & $\mathbf{7 , 5 8 7}^{\mathrm{b}}$ & $441,309^{\mathrm{b}}$ & $\mathbf{3 1 3 , 8 6 9}^{\mathrm{b}}$ \\
3 & $7,655^{\mathrm{c}}$ & $397,917^{\mathrm{a}}$ & $290,952^{\mathrm{a}}$ \\
\hline
\end{tabular}

Note: Numbers followed by different letters in the same row show significant differences in DMRT level of 5\%

Table 2. The average value of plant height, plant weight, number of leaves, number of flowers, root weight, length of root, and number of branches

\begin{tabular}{llll}
\hline \multirow{2}{*}{ Character } & \multicolumn{3}{c}{ Karangpandan } \\
\cline { 2 - 4 } & Accession 1 & Accession 2 & Accession 3 \\
\hline Plant height $(\mathrm{cm})$ & $20,18^{\mathrm{b}}$ & $15,78^{\mathrm{a}}$ & $21^{\mathrm{a}}$ \\
Number of leaves & $36,91^{\mathrm{b}}$ & $25,14^{\mathrm{a}}$ & $25,72^{\mathrm{a}}$ \\
Number of flowers & $10,62^{\mathrm{b}}$ & $6,31^{\mathrm{a}}$ & $5,65^{\mathrm{a}}$ \\
Plant weight $(\mathrm{g})$ & $198,59^{\mathrm{b}}$ & $126,40^{\mathrm{a}}$ & $106,03^{\mathrm{a}}$ \\
Root weight $(\mathrm{g})$ & $25,18^{\mathrm{c}}$ & $20,18^{\mathrm{b}}$ & $14,03^{\mathrm{a}}$ \\
Length of root $(\mathrm{cm})$ & $20,07^{\mathrm{b}}$ & $17,49^{\mathrm{a}}$ & $16,44^{\mathrm{a}}$ \\
Number of branch & $7,09^{\mathrm{b}}$ & $3,53^{\mathrm{a}}$ & $3,68^{\mathrm{a}}$ \\
\hline
\end{tabular}

Note: Numbers followed by different letters in the same column show significant differences in DMRT level of 5\%

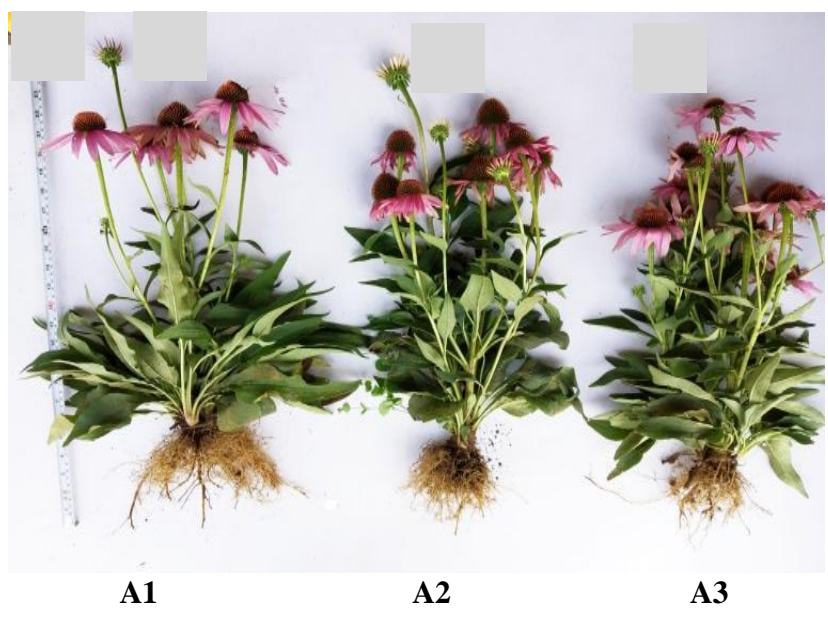

Figure 6. Whole plant morphology of E. purpurea used in this study: A1. Accession 1, A2. Accession 2, A3. Accession 3

Quantitative analysis shows that they are significant differences among accessions. Accession 1 significantly higher $(20,18 \mathrm{~cm})$ than Accession 2 and Accession 3 (with 15,78 and $14,71 \mathrm{~cm}$, respectively) (Table 2), while Accession 2 and Accession 3 no significant difference in height. Plant height is influenced by many factors, one of which is the height of the place, the E. purpurea parental used in this study came from a Tawangmangu Karanganyar, Central Java (highland) where the height of E. purpurea is almost identical to the one in its home country. The result is in accordance with research conducted by Almedi et al. (2018) which states that the height of sugarcane cultivated on lowland has the best average height than that cultivated on highland.
The number of leaves, number of flowers, plant weight, root length, and the number of branches showed significantly different results in which for these parameters. Accession 1 is the best compared to the two different other accessions (Fig 6). The number of leaves, the number of flowers and the number of branches in the lowland show significantly different results, but the ANOVA results show a lower number of leaves, number of stems and number of branches in comparison to E. purpurea cultivated in the highlands (unpublished data). This is influenced by a higher temperature that occurs in the lowland than the highland, further in a study conducted by Angio (2016) states that high temperatures can cause a decrease in the number of leaves, number of branches, plant height, and productivity of eggplant species.

For the root weight, all accessions show significant differences. A higher root weight indicates the greater root distribution due to adaptation towards the new habitat where it grows so that plants could grow well. The highest root weight, followed by plant growth, optimum stover weight, and plant height are shown by Accession 1. This is in accordance with the research by Nio and Torey (2013) that stated, plants that are resistant or adapt themselves to water shortages will have longer roots, higher root volume, and increased root dry weight. The fresh stover weight of the E. purpurea can be influenced by several factors such as accession, variety, altitude, temperature, sunlight intensity, etc. These factors affect the vegetative phase of E. purpurea, where most of the weight of fresh stover originates from leaves and stems. The yield of a crop is indeed strongly influenced by environmental conditions, altitude, water, sunlight, etc. This was stated by As-syakur et al. (2011), where sugarcane production is strongly influenced by biotic and abiotic factors, such as the altitude and temperature. 
This research concludes that there is a diversity of morphology of E. purpurea that is cultivated in the lowland. Morphological variations of accession E. purpurea can be distinguished and classified descriptively by observing the flowers, leaves, and stems. Morphological differences in E. purpurea are most visibly seen in the form of the flower and also the color of the stem. Morphological variations occurred due to many factors, among others, cross-pollination between accessions, altitude, temperature, water availability, and the composition of DNA. Accession 1 shows the best results compared to the other two accessions. Accession 1 in terms of plant height, number of leaves, number of flowers, plant weight, length of root, and number of branches height has the best adaptability if cultivated on lowland.

\section{ACKNOWLEDGEMENTS}

The authors thank the Center for Research and Development of Medicinal Plants and Traditional Medicine (B2P2TOOT), Tawangmangu, Indonesia and Sebelas Maret University, Surakarta, Indonesia for financial support.

\section{REFERENCES}

Acikgoz MA, Yarilgac T, Kara SM. 2017. Enhancement of phytochemical compounds using biotic and abiotic elicitors in purple coneflower (Echinacea purpurea (L.) Moench. Indian J Pharm Educ Res 52 (4): 140-145. DOI: 10.530/ijper.52.4s.90

Akram HM, Ali A, Sattar A, Rehman HSU, Bibi A. 2013. Impact of water deficit stress on various physiological and agronomic traits of three Basmati rice (Oryza sativa L.) cultivars. J Anim Plant Sci 23 (5): 1415-1423.

Alfian R, Susanti H. 2012. Determination of total phenolic content of methanol extract of red roselle petals (Hibiscus sabdariffa Linn.) with growth variations by spectrophotometric method. Sci J Pharm 2 (1): 73-80.

Almedi A, Soelistyono R. 2018. Effect of planting time and altitudes on the growth of Sugarcane (Saccharum officinarum L.). Jurnal Produksi Tanaman 6 (10): 2476-2481 [Indonesian]

Angio MH. 2016. The physiological and morphological responses of eggplant (Solanum melongena) to high-temperature stress. [Thesis]. Pascasarjana Institut Pertanian Bogor, Bogor. [Indonesian]

As-syakur AR. 2011. Identification of the relationship between SOI values and monthly rainfall in the Batukaru-Bedugul area, Bali. Jurnal Bumi Lestari 7 (2): 123-129 [Indonesian]

Banga D, Ardelean M, Duda M, Varban D. 2010. Phenotypical variability of several important characters at seven Echinacea purpurea cultivars tested in collection field of USAMV Cluj Napoca. Scientific Papers Agriculture Vol. 40 (1), USAMVB, Ed. Agroprint, Timișoara.

BPS. 2011. Karanganyar in figures. http //www.karanganyarkab.go.id/wpcontent/iploads/2015/04/Karanganyar-Dalam-Angka-2011.pdf [Indonesian]
Bruni R, Brighenti V, Caesar LK, Bertelli D, Cech NB, Pellati F. 2018. Analytical method for the study of bioactive compounds from medicinally used Echinacea species. Journal of pharmaceutical and Biomed Anal 160: 443-447

Center for Research and Development. 2010. Climate of the Indonesian Region. http://puslitbang.bmkg.go.if/litbang/wpcontent/uploads/2018/01/ikli,-kawasan-indonesia.pdf

Chang C, Yang M, Wen H, Chern J. 2002. Estimation of total flavonoid content in propolis by two complementary colorimetric methods. J Food Drug Anal 10: 178-182

Ditjen POM. 2000. Standart parameters of medicinal plant extracts. Ministry Health of Indonesia, Jakarta.

Heldt Piechulla. 2011. Plant Biochemistry. Academic Press, London.

Jones SB, Luchsinger AE. 1986. Plant Systematics. Second Edition. McGraw Hill Book Co., New York.

Kang HC, Ha YM, Kim KH. 2015. A new Hibiscus cultivar 'Woolred' with vigorous growth and unique flower shape through interspecific hybridization. Flower Res J 23 (4): 276-280. DOI: 10.11623/frj.2015.23.4.45

Lee TT, Huang CC, Shieh XH, Chen CL, Chen LJ, Yu B. 2010. Flavonoid, phenol and polysaccharide contents of Echinacea purpurea L. and its immunostimulant capacity in vitro. Intl J Environ Sci Dev 1 (1): 5-9.

Megha Gupta, Sharma D, Sharma A, Kumarl V, Goshain OP. 2012. A review on purple coneflower (Echinacea purpurea (L.) Moench). J Pharm Res 5 (8): 4076-4081.

Nijveldt, Nood V, Hoorn V, Boelens, Norren V, Leeuwen V. 2001. Flavonoids: a review of probable mechanism of action and potential applications. Am J Clin Nutr 74 (4): 418-425

Nio S.A., Torey P. 2013. Morphological character of the root as an indicator of lack of water in plants. Jurnal Bioslogos. 3 (1) 31-39 [Indonesian]

Pratiwi PY, Mardiyaningsih A, And Widarti E. 2019. Differences in the quality of hydroponic and conventional Mint (Mentha spicata L) plants based on plant morphology, chromatography profile, and essential oil content. Jurnal Riset Kefarmasian Indonesia. 1 (2): 148156. DOI: 10.33759/jrki.vli2.18 [Indonesian]

Purnobasuki H, Dewi AS, Wahyuni DK. 2014. Flower morphological variations in several varieties of Chrysanthemum morifolium Rahmat. Journal Natural B. 2 (3): 209-220 [Indonesian]

Rahardjo M, 2000. Echinacea as Potential herbal medicines. Warta Penelitian dan Pengembangan Tanaman Industri 6 (2): 1-3. [Indonesian]

Rahardjo M, 2005. Opportunities for E. purpurea cultivation in Indonesia. E-Journal Perspektif 4 (1): 1-10. [Indonesian]

Subositi D, Widiyastuti Y. 2013. Genetic diversity of accession of Ekinase (Echinacea purpurea (L.) Moench) from the results of year 1 mass selection through RAPD analysis. Buletin Kebun Raya. 16 (2): 93-100. [Indonesian]

Subositi D., Fauzi. 2012. Morphological variation of Ekinase (Echinacea purpurea (L.) Moench) accessions from mass selection year I on Medicinal Plant and Traditional Medicine Research and Development office (B2P2TOOT). Jurnal Penyakit Tidak Menular Indonesia 5 (2): 123-129 https: //ejurnal.litbang.pertanian.go.id/

Susila E, Susilowati A, Yunus A. 2019. The morphological diversity of Chrysanthemum resulted from gamma-ray irradiation. Biodiversitas 20: 463-467.

Tantasawat P, Trongchuen J, Prajongjai T, Seehalak W, Jittayasothorn Y. 2010. Variety identification and comparative analysis of genetic diversity in yardlong bean (Vigna unguiculata spp. sesquipedalis) using morphological characters, SSR and ISSR analysis. J Sci Hortic 124: 204-216.

Varban DI, Duda MM, Varban R, Muntean S, Muntean L. 2010. The study of several genotypes of Echinacea purpurea (L.) Moench. Res J Agric Sci 42 (1): 319-325. 